\title{
Covarying ionic conductances to emulate phase maintenance in stomatogastric neurons
}

\author{
Wafa Soofi ${ }^{1,2^{*}}$, Astrid Prinz ${ }^{2}$ \\ From Nineteenth Annual Computational Neuroscience Meeting: CNS*2010 \\ San Antonio, TX, USA. 24-30 July 2010
}

Neuronal networks produce reliable functional output throughout the lifespan of an animal despite ceaseless molecular turnover and a constantly changing environment. Central pattern generators, such as that of the crustacean stomatogastric ganglion (STG), robustly maintain their functionality over a wide range of burst periods [1]. Extracellular recordings of the LP neuron of the STG have demonstrated that as the burst period varies over time, the interspike intervals change proportionally, so that the spike phases are relatively invariant. This suggests that the regulation of intraburst spike patterns is of some functional importance, but the mechanism by which the network achieves this spike phase maintenance is not clear. It has further been experimentally observed that the coregulation of ion channel conductances may play a role in governing neuronal activity [2]. The present study utilized an existing database of conductance-based model neurons [3] to determine whether the pairwise covariance of certain conductances in an STG model neuron would result in neural output that emulates the experimentally observed phenomenon of phase maintenance. By computationally covarying all pairwise combinations of the eight membrane conductances, it was seen that the positive covariance of certain conductances, including sodium conductance and transient calcium conductance, causes the model neuron to maintain a specific spike phase pattern. Results indicate the possibility of a relationship between conductance coregulation and phase maintenance in lobster STG neurons.

\section{Author details}

'Department of Biomedical Engineering, Georgia Institute of Technology and Emory University, Atlanta, GA 30332, USA. ${ }^{2}$ Department of Biology, Emory University, Atlanta, GA 30322, USA.

\footnotetext{
* Correspondence: wsoofi@emory.edu

'Department of Biomedical Engineering, Georgia Institute of Technology and Emory University, Atlanta, GA 30332, USA
}

Published: 20 July 2010

\section{References}

1. Hooper SL: Phase maintenance in the pyloric pattern of the lobster (Panulirus interruptus) stomatogastric ganglion. J Comput Neurosci 1997, 4(3):191-205.

2. Schulz DJ, Goaillard JM, Marder E: Variable channel expression in identified single and electrically coupled neurons in different animals. Nat Neurosci 2006, 9:356-362.

3. Prinz AA, Billimoria CP, Marder E: Alternative to Hand-Tuning Conductance-Based Models: Construction and Analysis of Databases of Model Neurons. J Neurophysiol 2003, 90:3998-4015.

doi:10.1186/1471-2202-11-S1-P60

Cite this article as: Soofi and Prinz: Covarying ionic conductances to emulate phase maintenance in stomatogastric neurons. $B M C$ Neuroscience 2010 11(Suppl 1):P60.
Submit your next manuscript to BioMed Central and take full advantage of:

- Convenient online submission

- Thorough peer review

- No space constraints or color figure charges

- Immediate publication on acceptance

- Inclusion in PubMed, CAS, Scopus and Google Scholar

- Research which is freely available for redistribution

Submit your manuscript at www.biomedcentral.com/submit
C Biomed Central 